\title{
HANG-IN RATIO GILLNET DASAR DAN PENGARUHNYA TERHADAP KARAKTERISTIK HASIL TANGKAPAN LOBSTER (Panulirus SPP.) DI PALABUHANRATU JAWA BARAT
}

\author{
Hang-in Ratio Effect of Bottom Gillnet on Characteristic of Lobster (Panulirus spp.) in the \\ Palabuhanratu, West Java \\ Oleh: \\ Liya Tri Khikmawati ${ }^{*}$, Sulaeman Martasuganda ${ }^{2}$, Fedi Alfiadi Sondita ${ }^{2}$ \\ 1 Program Studi Teknologi Perikanan Laut, Institut Pertanian Bogor \\ 2 Departemen Pemanfaatan Sumberdaya Perikanan, Fakultas Perikanan dan Ilmu Kelautan, Institut Pertanian Bogor
}

${ }^{*}$ Korespondensi: liyatrikhikmawati@gmail.com

Diterima: 06 Januari 2017; Disetujui: 09 Oktober 2017

\begin{abstract}
Hang-in ratio $(H R)$ will determine the characteristics of lobster caught by bottom gillnet, e.g number, size (weight and length) and quality. Higher hang-in ratio means more net material needed per length unit to develop a set of bottom gillnet. At the same time, higher hang-in ratio may increase the probability of lobster being entangled, so it can decrease the quality of the catches. The purpose of this study was to determine the optimum design of bottom gillnet in Palabuhanratu, West Java by considering the effect of different hang-in ratio (52\%; $41 \%$ and $29 \%$ ) on the characteristics of lobster caught, easier of releasing the catches from the net, and the material needed. A field work was carried out to perform an experimental fishing consisted of 23 fishing trips during October to November 2016. Statistical tests did not show any effect of the hang-in ratio. Based on scoring method, the best hang-in ratio is $29 \%$ due to capture the number of types of catches at least, easier of releasing catches from the net and fewest material needed.
\end{abstract}

Keywords: bottom gillnet, hang-in ratio, lobster, Palabuhanratu

\begin{abstract}
ABSTRAK
Penggunaan hang-in ratio (HR) akan berpengaruh terhadap karakteristik hasil tangkapan lobster yang ditangkap dengan jaring insang dasar, seperti: jumlah, berat, panjang dan kualitas (kelengkapan tubuh). Penggunaan hang-in ratio yang besar akan meningkatkan penggunaan bahan atau mata jaring persatuan panjang dalam pembuatan satu unit jaring insang dasar. Penggunaan hang-in ratio yang besar pada jaring mengakibatkan semakin sulit lobster dilepaskan dari puntalan jaring karena tingkat kekenduran jaring yang tinggi. Jika tidak berhati-hati saat melepaskan lobster dari puntalan jaring dapat mematahkan bagian tubuh lobster (menurunkan kualitas hasil tangkapan). Tujuan penelitian adalah menentukan desain terbaik jaring insang dasar dengan melihat perbedaan hasil tangkapan, kemudahan melepaskan hasil tangkapan dari jaring dan penggunaan bahan jaring dari hang-in ratio yang berbeda, yaitu (52\%, 41\% dan $29 \%)$ di Palabuhanratu, Jawa Barat. Penelitian eksperimen ini dilaksanakan pada bulan Oktober sampai November 2016 dengan 23 kali trip penangkapan. Uji statistik penelitian menunjukkan bahwa dari ketiga jenis hang-in ratio tidak memberikan pengaruh yang signifikan terhadap karakteristik hasil tangkapan lobster. Namun, berdasarkan skoring HR terbaik yang digunakan pada jaring adalah
\end{abstract}


29\% karena menangkap jumlah jenis hasil tangkapan paling sedikit, lebih mudah melepaskan hasil tangkapan dari jaring, membutuhkan bahan jaring paling sedikit.

Kata kunci: lobster, jaring insang dasar, hang-in ratio, Palabuhanratu

\section{PENDAHULUAN}

Lobster merupakan salah satu produk perikanan ekspor Indonesia. Ekspor lobster pada tahun 2014 mencapai 3.427 ton senilai US\$ 42,8 juta (Ditjen P2HP 2015). Lobster memiliki nilai jual tinggi sesuai dengan jenis, berat dan kelengkapan tubuhnya. Palabuhanratu merupakan salah satu daerah yang memiliki potensi perikanan di pantai selatan Jawa Barat dimana perairannya berhubungan langsung dengan Samudera Hindia (Lubis dan Sumiati 2011; Budiarti 2012). Salah satu potensi perikanan Palabuhanratu adalah jenis lobster. Alat tangkap yang biasa digunakan nelayan di Palabuhanratu mulai dari alat tangkap pasif dan aktif seperti payang, pancing rawai, jodang, gillnet, pancing tonda dan longline (Nurani et al. 2012).

Salah satu jenis alat tangkap jaring yang digunakan adalah jaring insang dasar (jaring blo'on) yang biasa digunakan oleh nelayan di teluk Palabuhanratu untuk menangkap lobster (Panulirus sp.). Jaring blo'on ini memang menjadikan lobster mutiara sebagai spesies targetnya karena lobster mutiara memiliki nilai jual tertinggi daripada jenis lobster lainnya. Selain lobster, jika tertangkap ikan hasil tangkapan lain maka akan dimanfaatkan oleh nelayan untuk dijual atau dikonsumsi sendiri. Salah satu faktor yang memungkinan ikan tertangkap pada jaring insang dasar adalah hang-in ratio (HR) yang digunakan (Martasuganda et al. 1999). Hang-in ratio adalah presentase panjang bahan jaring yang direntang sempurna, dikurangi panjang jaring yang telah dipasang pada tali ris atas dan dibagi panjang bahan jaring yang direntang sempurna (Martasuganda 2008). Semakin tinggi HR yang digunakan maka jumlah bahan (mata jaring) persatuan panjang semakin banyak. Penggunaan hang-in ratio yang tinggi (jumlah mata jaring persatuan panjang semakin banyak) membuat jaring akan menangkap ikan secara terpuntal karena kekenduran jaring akan meningkat (Fridman 1986).

Hang-in ratio yang biasa digunakan nelayan jaring insang dasar di Palabuhanratu adalah 0,5234 (52\%). Sudah efisienkah penggunaan HR nelayan jaring insang dasar dalam menangkap lobster sebagai spesies target? Sedangkan hampir seluruh tubuh lobster dipenuhi duri. Adanya duri pada tubuh lobster memberikan peluang besar untuk lobster tertangkap dengan cara terpuntal pada jaring. Hang-in ratio tinggi membuat hasil tangkapan semakin terpuntal pada jaring karena jumlah mata persatuan panjang juga semakin banyak, akibatnya hasil tangkapan tersebut semakin sulit dilepaskan (Pet et al. 1995; Martasuganda et al. 2000).

Kesulitan melepaskan lobster yang terpuntal pada jaring memungkinkan patahnya bagian tubuh lobster jika nelayan tidak berhatihati. Selama ini jika nelayan mendapatkan hasil tangkapan lobster yang sangat terpuntal pada jaring, mereka melepaskan lobster dengan cara memotong jaring. Hal ini dilakukan untuk mempertahankan kualitas lobster dimana tidak ada bagian tubuh yang rusak. Namun demikian, pemotongan jaring secara terus menerus akan merugikan nelayan.

Upaya perbaikan terhadap desain lobster bottom gillnet yang ada di Palabuhanratu adalah dengan mengubah ukuran HR dari jaring menjadi lebih kecil. Perubahan hang-in ratio jaring ditujukan untuk memberikan peluang hasil tangkapan yang berukuran kecil dapat melewati jaring (meloloskan diri) (Acosta dan Appeldoorn 1995; Pet et al. 1995), memudahkan nelayan melepaskan hasil tangkapan dari jaring (Samaranayaka et al. 1997) dan mengefisienkan penggunaan bahan jaring (Mohammed 2015). Selain itu, pengurangan nilai HR akan memperkecil terjeratnya ikan hasil tangkapan sampingan (Pet et al. 1995). Ikan yang akan terjerat adalah ikan dengan ukuran besar. Pengetahuan mengenai alat tangkap dan hasil tangkapan merupakan faktor penting dalam mewujudkan efektivitas dan efisiensi kegiatan penangkapan ikan (Syofyan et al. 2010; Haluan et al. 2012)

Upaya perbaikan efisiensi konstruksi jaring insang dasar telah dilakukan oleh beberapa peneliti. Perbedaan penggunaan HR jaring terhadap selektifitas alat tangkap jaring sudah dilakukan oleh Emmanuel et al. (2008) untuk ikan pelagis; Hutubessy (2011) untuk ikan selar serta Orsay dan Murside (2011) untuk ikan sedangkan perbedaan penggunaan HR terhadap efisiensi jaring untuk menangkap ikan tuna telah dilakukan oleh Parsa et al. (2014). Namun, dari semua penelitian yang telah dilakukan tersebut belum ada yang mengamati secara khusus terhadap lobster.

Penelitian dilakukan dengan membuat desain jaring baru yang memiliki HR berbeda dari yang digunakan nelayan. Pemilihan HR dilakukan berdasarkan studi sebagaimana dije- 
laskan dalam Martasuganda (2008). Setelah ditemukan HR yang sesuai, akan dibuat desain jaring dan diuji cobakan secara langsung dilapang. Adapun tujuan penelitian ini adalah untuk menentukan desain jaring insang dasar yang terbaik untuk menangkap lobster dengan menganalisis pengaruh HR terhadap karakteristik hasil tangkapan lobster, kemudahan melepaskan lobster dari jaring, efisiensi penggunaan bahan jaring dan jumlah jenis hasil tangkapan. Karakteristik yang dimaksud meliputi: jumlah, ukuran (panjang dan berat), dan kelengkapan tubuh lobster yang tertangkap.

\section{METODE}

Penelitian dilakukan dengan mengoperasikan jaring yang telah dibuat (experimental fishing) di perairan Palabuhanratu, Sukabumi, Jawa Barat pada bulan Oktober-November 2016. Daerah pengoperasian berjarak sekitar 2 mil dari daratan pada kedalaman hingga $15 \mathrm{~m}$, dengan dasar perairan lumpur berpasir. Adapun lokasi penelitian dapat dilihat pada Gambar 1.

Eksperimen dilakukan menggunakan 3 jenis jaring insang dasar dengan HR berbeda dan diulang sebanyak 23 kali. Jaring dengan $\mathrm{HR}$ yang pertama adalah yang biasa digunakan nelayan yaitu $52 \%$ (HR52). Jaring dengan HR yang berikutnya adalah HR dengan ukuran lebih kecil dengan tujuan agar dapat meloloskan lobster berukuran kecil, sehingga ukuran HR kedua yang digunakan sebesar 29\% (HR29). Bukaan mata jaring berbentuk belah ketupat (memiliki tinggi dan lebar mata jaring sama) nilai HRnya adalah $29,3 \%$ sehingga memungkinkan lobster berukuran kecil melewati jaring dan kelenturan jaring akan berkurang (Martasuganda 2008). Jaring ketiga memiliki nilai HR $41 \%$ yang merupakan nilai tengah dari dari dua nilai HR jaring lainnya. Penggunaan jumlah mata jaring yang digunakan pada alat tangkap untuk bagian tali ris atas dan tali ris bawah, dihitung berdasarkan persamaan yang dibuat oleh Martasuganda (2008):

Sa $(\%)=(L-L a) / L \times 100 \%$

$S b(\%)=(L-L b) / L X 100 \%$

dengan:

Sa = hang-in ratio bagian tali ris atas;

$S b=$ hang-in ratio bagian tali ris bawah;

$L=$ panjang bahan jaring direntang sempurna;

La = panjang jaring setelah dipasang pada tali ris atas; dan

$L b=$ panjang jaring setelah dipasang pada tali ris bawah

Jaring dengan ukuran HR yang berbeda dirangkai menjadi satu, dimana masing-masing HR berjumlah 2 piss, sehingga total jaring yang digunakan dalam penelitian adalah 6 piss (Gambar 2) (Samaranayaka et al. 1997). Hal tersebut dilakukan untuk memberikan peluang yang sama pada setiap desain untuk menangkap ikan. Pengaruh perbedaan waktu pengoperasian dan lokasi pemasangan alat dapat dihilangkan sehingga perbedaan hanya terdapat pada desainnya saja. Penentuan titik sampling berdasarkan pertimbangan atau kebiasaan nelayan mengoperasikan alat tangkap yang dianggap memiliki potensi lobster.

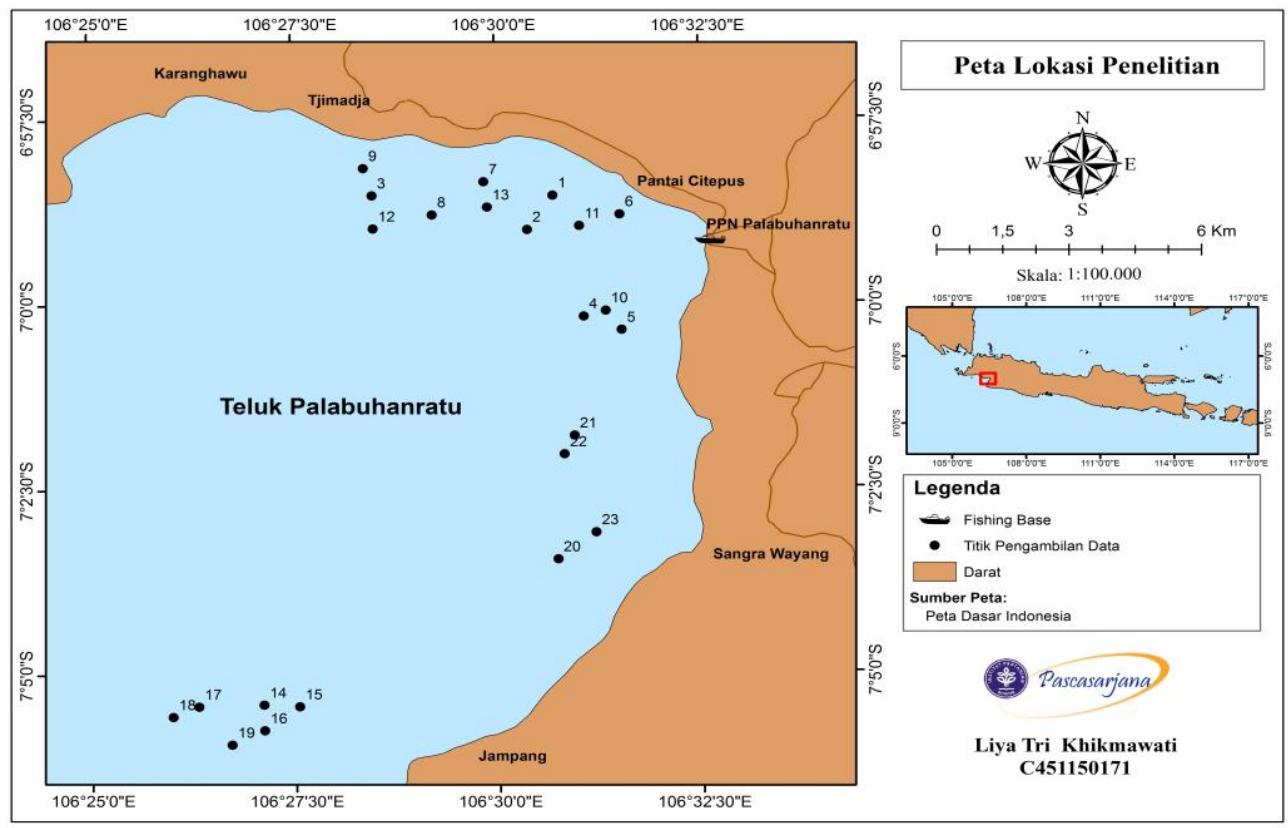

Gambar 1 Peta lokasi penelitian 


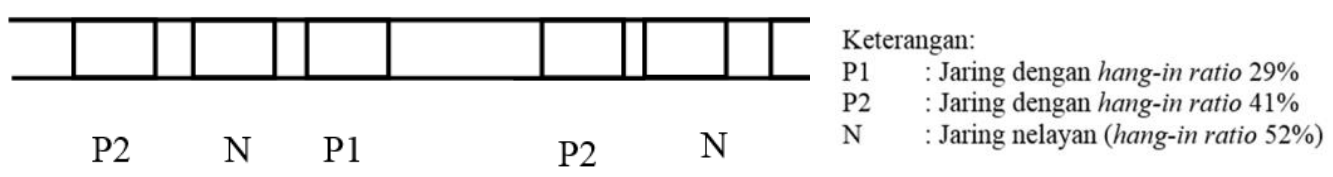

Gambar 2 Model pemasangan jaring dalam eksperimen

Tabel 1 Perhitungan untuk menentukan jaring lobster terbaik di Palabuhanratu

\begin{tabular}{|c|c|c|c|}
\hline & \multicolumn{2}{|c|}{ Desain Jaring $(D)$} & \\
\hline Indikator $(I)$ & HR 52\% & HR $41 \%$ & HR 29\% \\
\hline 1. Rata-rata jumlah tangkapan per trip & $R_{1,1}$ & $R_{2,1}$ & $R_{3,1}$ \\
\hline 2. Proporsi lobster berukuran legal & $R_{1,1}$ & $R_{2,1}$ & $R_{3,1}$ \\
\hline 3. Proporsi lobster dengan tubuh utuh & $R_{1,2}$ & $R_{2,2}$ & $R_{3,2}$ \\
\hline 4. Kemudahan melepaskan lobster dari jaring & $R_{1,3}$ & $R_{2,3}$ & $R_{3,3}$ \\
\hline 5. Kebutuhan bahan jaring & $R_{1,4}$ & $R_{2,4}$ & $R_{3,4}$ \\
\hline 6. Komposisi jenis hasil tangkapan & $D_{1,6}$ & $D_{2,6}$ & $D_{3,6}$ \\
\hline Jumlah & $\sum_{D=1}^{1,6}(D)$ & $\sum_{D=2}^{2,6}(D)$ & $\sum_{N=2.6}^{3.6}(D)$ \\
\hline
\end{tabular}

Metode pengoperasian alat tangkap sesuai dengan yang biasa dilakukan oleh nelayan, yaitu pemasangan alat tangkap dilakukan pada sore hari (Pukul 17.00 WIB) dengan posisi pemasangan alat seperti pada Gambar 2. Alat akan direndam selama semalam. Proses pengangkatan alat dilakukan pada pagi harinya pukul (05.00 WIB). Setelah proses pengangkatan selesai dan hasil tangkapan sudah diambil semua, maka alat tangkap akan direndam kembali di laut. Keesokan harinya pukul 05.00 WIB nelayan akan kembali ke tempat pemasangan alat untuk mengambil hasil tangkapan, begitu seterusnya. Untuk mengetahui posisi pemasangan alat tangkap, nelayan menggunakan pelampung penanda pada alat tersebut.

Hasil tangkapan lobster yang diperoleh pada setiap percobaan dikumpulkan untuk selanjutnya dianalisis. Adapun data yang dikumpulkan adalah data karakteristik hasil lobster, yaitu: jenis lobster, jumlah (ekor), panjang karapas $(\mathrm{cm})$, berat $(\mathrm{g})$, dan kelengkapan bagian tubuh. Pengukuran panjang karapas dan berat tangkapan lobster dilakukan untuk melihat tingkat kelayakan hasil tangkapan menurut peraturan yang berlaku. Berdasarkan peraturan Nomor 56/PERMEN-KP/2016 tentang larangan penangkapan dan/atau pengeluaran Lobster ( $\mathrm{Pa}$ nulirus spp.), Kepiting (Scylla spp.), dan Rajungan (Portunus pelagicus spp.) dari wilayah Negara Republik Indonesia hanya dapat dilakukan dengan ketentuan berukuran panjang karapas lebih dari $8 \mathrm{~cm}$ atau ukuran berat lebih dari $200 \mathrm{~g}$ per ekor. Lobster akan dikatakan tidak layak ketika memiliki berat $\leq 200 \mathrm{~g}$ atau memiliki panjang karapas $\leq 8 \mathrm{~cm}$. Berdasarkan ukuran panjang karapas dan berat tersebut ditentukan presentase lobster yang layak tangkap pada setiap ulangan percobaan. Kelengkapan hasil tangkapan lobster akan diklasifikasikan menjadi dua kategori sesuai dengan pasar ekspor lobster yaitu normal dan second. Lobster dikatakan normal jika memiliki tubuh yang utuh dan jika ada bagian tubuh lobster yang patah maka tidak lebih dari 2 bagian. Kategori second apabila bagian tubuh lobster patah lebih dari 2 bagian tubuh dan terletak pada sisi yang sama.

Ada tidaknya perbedaan jumlah (ekor) dan presentase layak tangkap (panjang dan berat) dari ketiga jaring yang diujicobakan dapat diketahui dengan melakukan uji nonparametrik dengan Kruskal Wallis Test. Penggunaan test nonparametrik dilakukan ketika data yang diperoleh memiliki varian sama namun tidak menyebar normal. Prosedur uji Kruskal Wallis adalah:

1. Hipotesis

$\mathrm{H}_{0}$ : tidak ada perbedaan nilai median populasi dari percobaan ketiga jenis HR

$\mathrm{H}_{1}$ : ada perbedaan nilai median populasi dari percobaan ketiga jenis $\mathrm{HR}$

2. Taraf nyata atau taraf signifikansi (a): 0,05

3. Statistik uji:

$$
H=\frac{12}{N(N+1)} \sum_{j=1}^{k} \frac{R_{j}^{2}}{n_{j}}-3(N+1)
$$

4. Kriteria keputusan

Menolak $\mathrm{H}_{0}$ jika $H_{\text {hitung }} \geq \chi_{\alpha}^{2}$ atau $P_{\text {value }}<\alpha$, nilai chi-kuadrat $\left(\chi^{2}\right)$

(Walpole 1995)

Penentuan desain jaring insang terbaik dari tiga desain jaring dengan HR berbeda $(d)$ dilakukan dengan menerapkan metode pemberian skor (scoring) yang mempertimbangkan 5 indikator (I), yaitu jumlah hasil tangkapan per trip, proporsi lobster berukuran legal $(\mathrm{CL}>8 \mathrm{~cm}$ atau berat $>200 \mathrm{~g}$ ), proporsi lobster dengan tubuh yang utuh, kemudahan melepaskan lobster dari jaring, serta jumlah bahan jaring yang di- 
perlukan untuk membuat satu pis jaring (m). Dalam penelitian ini, setiap indikator memiliki kontribusi yang sama dalam menentukan desain jaring terbaik. Skoring dilakukan dengan membandingkan peringkat (ranking) dari nilai indikator antar jaring dengan desain yang berbeda.

Penilaian setiap indikator dilakukan dengan cara mengurutkan 3 nilai dari tertinggi ke terendah. Penilaian untuk 3 indikator pertama, jaring dengan nilai tertinggi diberi skor 3 , jaring dengan nilai terendah diberi nilai 1 dan jaring dengan nilai di antara tertinggi dan terendah diberi skor 2. Indikator keempat, berdasarkan wawancara dengan nelayan, semakin mudah nelayan melepaskan lobster dari jaring maka diberi skor 3 dan semakin sulit melepaskan lobster diberi skor 1. Sedangkan skor 2 untuk biasa saja ketika melepaskan lobster dari jaring. Untuk indikator kelima (jumlah bahan jaring), jaring dengan jumlah bahan terkecil diberi skor 3 sedangkan jaring dengan jumlah bahan terbanyak diberi skor 1 . Indikator keenam, semakin sedikit komposisi jenis hasil tangkapan maka akan diberi nilai maksimal yaitu 3. Semakin banyak komposisi jenis hasil tangkapan maka akan diberi nilai minimal yaitu 1 . Nilai 2 diberikan pada nilai antara komposisi jenis hasil tangkapan maksimal dan minimal. Hasil penelitian tersebut adalah skor setiap indikator $\left(R_{d i}\right)$. Jumlah skor dari setiap indikator kemudian dihitung untuk masing-masing jaring. Jaring de- ngan jumlah skor tertinggi dinyatakan sebagai jaring terbaik untuk menangkap lobster.

Desain jaring terbaik adalah jaring dengan kemampuan untuk menangkap lobster berukuran legal terbanyak, memiliki tubuh utuh yang terbanyak, dan mudah dilepaskan dari jaring serta memerlukan bahan jaring dalam jumlah tersedikit dan jaring menangkap jenis ikan lain dalam jumlah yang paling sedikit.

\section{HASIL \\ Desain Jaring Insang Dasar}

Desain jaring insang dasar dihitung berdasarkan HR yang telah ditentukan sebelumnya dengan mengubah jumlah mata antar pelampung dan pemberat. Desain konstruksi jaring insang dasar dapat dilihat pada Gambar 3.

Konstruksi jaring insang dasar dengan HR berbeda membutuhkan banyaknya bahan jaring yang berbeda. Perbedaan ini terjadi sebagai akibat dari perubahan jumlah mata antar pelampung dan pemberat (Tabel 2).

\section{Komposisi Total Hasil Tangkapan}

Pengoperasian jaring insang dasar penelitian sebanyak 2 pis untuk masing-masing jenis HR menangkap berbagai jenis ikan. Komposisi hasil tangkapan untuk masing-masing jaring dengan HR berbeda terdapat pada Tabel 2 .

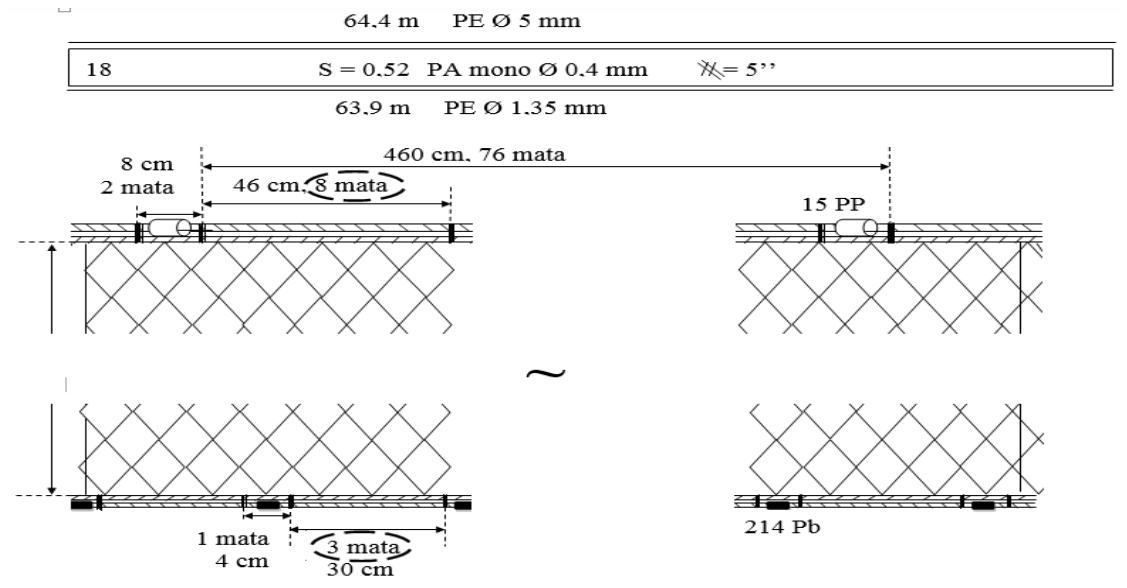

Gambar 3 Desain jaring insang dasar biasa digunakan nelayan Palabuhanratu (1 pis)

Tabel 2 Penggunaan bahan jaring-jaring insang dasar Jumlah mata jaring Jumlah mata antar ikat pada tali jaring antar ris atas $(46 \mathrm{~cm})$

$\begin{array}{cc}\begin{array}{c}\text { Jumlah mata } \\ \text { jaring pada tali ris } \\ \text { bawah per pis } \\ (63,90 \mathrm{~m})\end{array} & \begin{array}{c}\text { Jumlah mata } \\ \text { Setiap 17 pis }\end{array} \\ 639 & 10.863 \\ 852 & 14.484 \\ 1.065 & 18.105\end{array}$


Tabel 2 Komposisi total hasil tangkapan dengan HR berbeda selama 23 trip penangkapan dengan 6 pis jaring

\begin{tabular}{|c|c|c|c|c|c|c|c|}
\hline \multirow[b]{2}{*}{ No } & \multirow[b]{2}{*}{ Jenis Hasil Tangkapan } & \multicolumn{2}{|c|}{$52 \%$} & \multicolumn{2}{|c|}{$41 \%$} & \multicolumn{2}{|c|}{$29 \%$} \\
\hline & & $\begin{array}{l}\text { Jumlah } \\
\text { (ekor) }\end{array}$ & $\begin{array}{c}\text { Berat } \\
(\mathrm{g})\end{array}$ & $\begin{array}{l}\text { Jumlah } \\
\text { (ekor) }\end{array}$ & $\begin{array}{l}\text { Berat } \\
(\mathrm{g})\end{array}$ & $\begin{array}{l}\text { Jumlah } \\
\text { (ekor) }\end{array}$ & $\begin{array}{l}\text { Berat } \\
(\mathrm{g})\end{array}$ \\
\hline 1 & $\begin{array}{l}\text { Lobster Mutiara (Panulirus } \\
\text { ornatus) } \\
\text { Lobster bambu (Panulirus }\end{array}$ & (1) & 810 & (0) & 320 & (ons) & 1192 \\
\hline 2 & versicolor) & 1 & 429 & & & & \\
\hline 3 & $\begin{array}{l}\text { Sebelah (Pleuronectes sp.) } \\
\text { Sedapang waru (Drepane }\end{array}$ & 5 & 1040 & 4 & 1260 & & \\
\hline 4 & punctata) & 16 & 3670 & 1 & 163 & & \\
\hline 5 & Udang (Penaeus sp.) & 9 & 940 & 3 & 120 & & \\
\hline 6 & Kerapu (Epinephelus sp.) & 3 & 710 & 2 & 720 & 1 & 80 \\
\hline 7 & Ayam-ayam (Abalistes stellaris) & 2 & 1200 & 1 & 600 & 1 & 720 \\
\hline 8 & Kepiting (Scylla sp.) & 55 & 6040 & 17 & 1662 & 13 & 1462 \\
\hline 9 & Keong (Gibbula sp. ) & 3 & 1392 & & & 1 & 47 \\
\hline 10 & Kakap (Lates calcafier) & 1 & 700 & & & 3 & 1760 \\
\hline 11 & Pari (Dasyatis sp.) & 2 & 1800 & & & 1 & 200 \\
\hline 12 & $\begin{array}{l}\text { Bete (Leiognathus equulus) } \\
\text { Samgeh (Pseudociena }\end{array}$ & 5 & 2320 & & & & \\
\hline 13 & $\begin{array}{l}\text { amoyensis) } \\
\text { Biji Nangka (Upeneus }\end{array}$ & 1 & 61 & & & & \\
\hline 14 & sulphureus) & 2 & 40 & & & & \\
\hline 15 & Kwee (Caranx sexfasciatus) & 1 & 3000 & & & & \\
\hline 16 & Belut Laut (Gymnothorax spp.) & 2 & 8000 & & & & \\
\hline \multirow{2}{*}{$\begin{array}{l}17 \\
18\end{array}$} & Kembung (Rastrelliger sp.) & 1 & 80 & & & & \\
\hline & Bawal Putih (Pampus argentus) & & & 1 & 365 & & \\
\hline 19 & Ekor Kuning (Caesio sp.) & & & 1 & 83 & & \\
\hline 20 & Udang Kipas (Thenus orientalis) & & & 1 & 80 & & \\
\hline 21 & Rajungan (Portunus) & & & 4 & 169 & 4 & 241 \\
\hline 22 & Bogot (Aluterus monoceros) & 1 & 50 & & & & \\
\hline 23 & $\begin{array}{l}\text { Ikan Bakuku (Etelis oculatus) } \\
\text { Ikan Camaul (Priacanthus }\end{array}$ & 3 & 1550 & & & & \\
\hline 24 & $\begin{array}{l}\text { tayanus) } \\
\text { Ikan Singrang (Lutjanus }\end{array}$ & 2 & 280 & & & & \\
\hline 25 & $\begin{array}{l}\text { synagris) } \\
\text { Ikan Cawane (Caesio }\end{array}$ & 6 & 280 & & & & \\
\hline 26 & erythrogaster) & 1 & 80 & & & & \\
\hline 27 & Ikan Suir (Lates calcarifer) & 1 & 1400 & & & & \\
\hline 28 & $\begin{array}{l}\text { Ikan Kadal (Echeneida spp.) } \\
\text { Ikan Boce (Nemipterus }\end{array}$ & 4 & 1080 & 1 & 320 & 2 & 320 \\
\hline 29 & nematophorus) & 1 & 40 & 1 & 40 & 1 & 80 \\
\hline 30 & $\begin{array}{l}\text { Torontong (Caranx sexfasciatus) } \\
\text { Ikan Banteng (Lagocephalus }\end{array}$ & 9 & 1730 & & & 1 & 200 \\
\hline 31 & spp.) & & & 1 & 65 & & \\
\hline 32 & $\begin{array}{l}\text { Gerbah (Charybdis natator) } \\
\text { Ikan Lepo Batu/Gelang Hantu (Pteroi }\end{array}$ & & & 1 & 137 & & \\
\hline \multirow[t]{2}{*}{33} & voltans) & & & & & 1 & 160 \\
\hline & Jumlah & 26 & 38722 & 15 & 6104 & 12 & 6462 \\
\hline
\end{tabular}


Berdasarkan uji coba di lapang, jaring dengan HR 52\% menangkap 26 jenis ikan termasuk lobster mutiara dan lobster bambu. Jaring dengan HR $41 \%$ menangkap 15 jenis ikan termasuk lobster mutiara. Jaring dengan HR $12 \%$ menangkap paling sedikit jenis ikan hasil tangkapan yaitu 12 jenis ikan termasuk lobster mutiara.

\section{Karakteristik Hasil Tangkapan Lobster}

Karakteristik hasil tangkapan yang dikaji meliputi jumlah, proporsi lobster layak tangkap dan kelengkapan tubuh lobster. Jumlah hasil tangkapan lobster setelah dilakukan uji coba di lapang adalah seperti yang terdapat pada Tabel 3.

Tabel 3 Jumlah hasil tangkapan lobster dengan HR berbeda selama 23 trip penangkapan

\begin{tabular}{lcccc}
\hline \multirow{2}{*}{ Jenis Hasil Tangkapan } & \multicolumn{3}{c}{ HR } & Jumlah \\
\cline { 2 - 4 } & $52 \%$ & $41 \%$ & $29 \%$ & (ekor) \\
\hline Lobster Mutiara (Panulirus ornatus) & 4 & 1 & 5 & 10 \\
Lobster bambu (Panulirus versicolor) & 1 & 0 & 0 & 1 \\
\hline Jumlah & 5 & 1 & 5 & 11 \\
\hline
\end{tabular}

Jenis lobster yang tertangkap terdiri dari 2 jenis yaitu lobster mutiara sebanyak 10 ekor dan lobster bambu 1 ekor (Tabel 3). Penggunaan $\mathrm{HR}$ jaring $52 \%$ menghasilkan tangkapan lobster sebanyak 5 ekor dengan lobster mutiara sebanyak 4 ekor dan lobster bambu sebanyak 1 ekor (Gambar 4). Jaring dengan HR 41\% hanya dapat menangkap 1 ekor lobster mutiara.

Desain yang ketiga yaitu jaring dengan HR 29\% menangkap 5 ekor lobster mutiara. Jika dilihat secara keseluruhan maka penggunaan $H R$ memberikan perbedaan terhadap hasil tangkapan. Jaring dengan HR $52 \%$ dan HR 29\% menangkap lobster lebih banyak daripada menggunakan HR $41 \%$.

Setelah dilakukan uji Kruskal Wallis didapatkan nilai $\operatorname{sig} 0,339$. Nilai tersebut lebih besar dari alpha $(0,05)$ sehingga dapat disimpulkan bahwa perbedaan HR tidak memberikan pengaruh terhadap jumlah hasil tangkapan lobster. Secara statistik, jumlah hasil tangkapan lobster ketiga desain HR adalah sama.

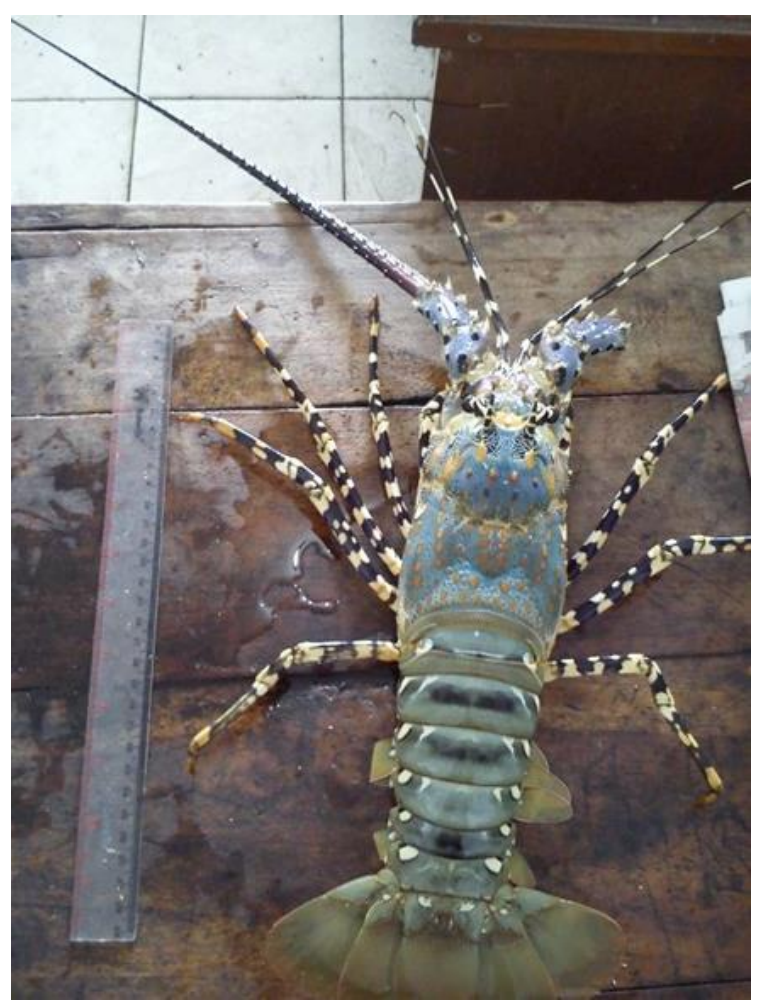

Lobster mutiara (Panulirus ornatus)

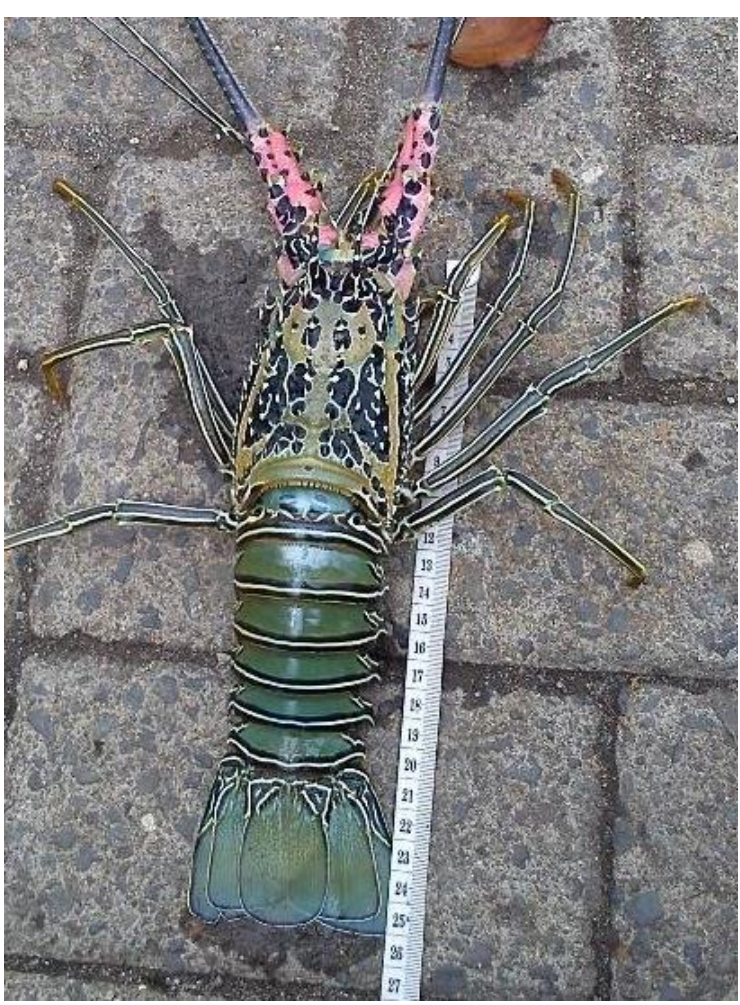

Lobster bambu (Panulirus versicolor)

Gambar 4 Lobster hasil tangkapan penelitian 
Tabel 4 Ukuran hasil tangkapan lobster dengan HR berbeda selama 23 trip penangkapan

\begin{tabular}{|c|c|c|c|c|c|c|c|c|c|}
\hline \multirow{3}{*}{ Jenis } & \multicolumn{9}{|c|}{ HR } \\
\hline & \multicolumn{3}{|c|}{$52 \%$} & \multicolumn{3}{|c|}{$41 \%$} & \multicolumn{2}{|c|}{$29 \%$} & \multirow[b]{2}{*}{ Kelayakan } \\
\hline & $\begin{array}{c}\text { Berat } \\
\text { (gram) }\end{array}$ & $\begin{array}{l}\text { PK } \\
(\mathrm{cm})\end{array}$ & Kelayakan & $\begin{array}{c}\text { Berat } \\
\text { (gram) }\end{array}$ & $\begin{array}{l}\mathrm{PK} \\
(\mathrm{cm})\end{array}$ & Kelayakan & $\begin{array}{c}\text { Berat } \\
\text { (gram) }\end{array}$ & $\begin{array}{l}\text { PK } \\
(\mathrm{cm})\end{array}$ & \\
\hline Mutiara & 150 & 7,5 & $\mathrm{TL}$ & 320 & 11 & $L$ & 200 & 10 & $L$ \\
\hline Mutiara & 110 & 8 & $\mathrm{TL}$ & - & - & - & 301 & 8,6 & L \\
\hline Mutiara & 350 & 12 & L & - & - & - & 285 & 8,6 & L \\
\hline Mutiara & 200 & 9 & L & - & - & - & 206 & 7,7 & L \\
\hline Mutiara & - & - & - & - & - & - & 200 & 7,5 & $\mathrm{TL}$ \\
\hline Bambu & 429 & 14 & L & - & - & - & - & - & - \\
\hline
\end{tabular}

Kelayakan hasil tangkapan ditentukan berdasarkan berat atau panjang karapas dan digolongkan ke dalam 2 (dua) kategori, yaitu layak tangkap dan tidak layak tangkap. Proporsi lobster yang layak tangkap dari ketiga jenis HR dapat dilihat pada Tabel 4.

Ketiga jaring menangkap lobster dengan panjang dan berat yang bervariasi (Tabel 4). Penggunaan HR 52\% menangkap lobster yang layak tangkap sebanyak 3 ekor (60\%), tidak layak tangkap sebanyak 2 ekor. Begitu juga lobster mutiara 1 ekor yang tertangkap pada jaring HR 41\% memiliki ukuran yang sudah layak tangkap (100\%). Jaring dengan HR 29\% menangkap lobster mutiara sebanyak 4 ekor $(80 \%)$ yang layak tangkap dan 1 ekor lobster mutiara yang tidak layak. Secara keseluruhan dapat dikatakan bahwa lobster yang tertangkap selama percobaan, 72,73 \% sudah layak tangkap dan 27,27\% belum layak tangkap.

Pengujian statistik dilakukan dengan menggunakan uji Kruskal Wallis untuk mengetahui apakah ada perbedaan proporsi lobster yang layak tangkap pada ketiga desain jaring. Hasil pengujian memperoleh nilai sig sebesar 0,427. Nilai tersebut lebih besar dari $\alpha$ $(0,05)$ sehingga dapat disimpulkan bahwa tidak terdapat perbedaan proporsi lobster yang layak tangkap pada ketiga desain jaring.Kelengkapan lobster hasil tangkapan diklasifikasikan menjadi 2 kategori yaitu lengkap dan second. Hasil pengamatan kelengkapan hasil tangkapan lobster selama penelitian disajikan pada Tabel 5 .

Tabel 5 menunjukkan bahwa lobster yang tertangkap baik pada HR $52 \%, 41 \%$ dan $29 \%$ adalah sama, yaitu memiliki bagian tubuh yang lengkap. Secara keseluruhan dapat dikatakan bahwa semua lobster yang tertangkap selama penelitian memiliki bagian tubuh lengkap.

Berdasarkan wawancara selama kegiatan penangkapan lobster yang diikuti secara langsung oleh peneliti, nelayan menyatakan bahwa lobster dan ikan hasil tangkapan lain yang terpuntal pada jaring dengan desain HR $29 \%$ lebih mudah untuk dilepaskan daripada desain yang lainnya. Semakin tinggi HR, puntalan terhadap hasil tangkapan pada jaring semakin sulit dilepaskan.

Penentuan pemilihan desain jaring terbaik untuk menangkap lobster berdasarkan 5 indikator yang sudah ditentukan sebelumnya. Penilaian terhadap indikator-indikator tersebut terdapat pada Tabel 6.

Berdasarkan rekapitulasi skor peringkat desain jaring untuk setiap indikator (Tabel 6), jaring insang dasar dengan HR 29\% memiliki jumlah nilai yang paling tinggi sehingga dapat dikatakan bahwa jaring dengan desain HR $29 \%$ adalah yang terbaik untuk menangkap lobster di Palabuhanratu.

Tabel 5 Kelengkapan hasil tangkapan lobster dengan HR berbeda selama 23 trip penangkapan

\begin{tabular}{lccc}
\hline Jenis & & HR & \\
\hline & $52 \%$ & $41 \%$ & $29 \%$ \\
\hline Lobster mutiara & Lengkap & Lengkap & Lengkap \\
Lobster mutiara & Lengkap & - & Lengkap \\
Lobster mutiara & Lengkap & - & Lengkap \\
Lobster mutiara & Lengkap & - & Lengkap \\
Lobster mutiara & - & - & Lengkap \\
Lobster bambu & Lengkap & - & - \\
\hline
\end{tabular}


Tabel 6 Skoring terhadap indikator penentu pemilihan desain jaring terbaik di Palabuhanratu

\begin{tabular}{lccc}
\hline & \multicolumn{3}{c}{ Desain Jaring $(D)$} \\
\hline Indikator (I) & HR 52\% & HR 41\% & HR 29\% \\
\hline 1. Jumlah hasil tangkapan lobster per trip & 1 & 1 & 1 \\
2. Proporsi lobster berukuran legal & 1 & 1 & 1 \\
3. Proporsi lobster dengan tubuh utuh & 1 & 1 & 1 \\
4. Kemudahan melepaskan lobster dari jaring & 1 & 2 & 3 \\
5. Kebutuhan bahan jaring & 1 & 2 & 3 \\
\hline 6. Komposisi jenis hasil tangkapan jaring & 1 & 2 & 3 \\
\hline Jumlah & 6 & 9 & 12 \\
\hline
\end{tabular}

\section{PEMBAHASAN}

Saat penelitian dilaksanakan, jumlah hasil tangkapan lobster relatif lebih sedikit walaupun penelitian sudah dilakukan pada musim penangkapan lobster yaitu bulan Oktober hingga November. Menurut Sobari et al. (2008), musim penangkapan spiny lobster terjadi pada musim penghujan yaitu pada bulan September sampai Februari. Pemilihan daerah penangkapan yang berbeda-beda sesuai dengan kebiasaan nelayan menangkap lobster pada lokasi yang potensial mendapatkan lobster. Berbeda daerah memungkinkan terjadi perbedaan ukuran lobster yang disebabkan oleh perbedaan kondisi lingkungan dan tekanan penangkapan di masing-masing lokasi tersebut (Kembaren dan Nurdin 2015). Hal tersebut kemungkinan disebabkan oleh faktor oseanografi lingkungan daerah penangkapan. Cuaca yang tidak menentu membuat lobster berada lebih tenang di dasar perairan. Berbeda ketika kondisi dasar perairan berarus kuat sehingga memungkinkan lobster untuk bergerak terbawa arus yang kemudian dapat terpuntal pada jaring. Menurut Fonseca et al. (2005); Zulkarnain (2012), salah satu faktor yang mempengaruhi keberhasilan suatu kegiatan penangkapan baik dalam jumlah maupun ukuran adalah kondisi ikan target tangkapan.

Produksi lobster yang rendah untuk setiap nelayan tergambar dengan hasil tangkapan nelayan setiap melaut yang sedikit. Berdasarkan pengamatan di lapang selama bulan Oktober-November setiap nelayan yang melaut jarang mendapatkan lobster, kalaupun mendapatkan lobster, dari 50 pis yang dipasang hanya mendapatkan 1 sampai 2 ekor lobster. Saat penelitian dilakukan, hasil tangkapan lobster diperoleh hanya dari total 6 pis jaring dimana masing-masing jenis HR memiliki 2 pis jaring. Selain itu adanya isu penurunan stok akibat penangkapan benur oleh sebagian nelayan di $\mathrm{Pa}$ labuhanratu diduga sebagai penyebab menurunnya hasil tangkapan lobster. Adanya isu penurunan stok sumberdaya ikan dan over fishing maka pemilihan dan penggunaan alat tangkap menjadi lebih selektif (Mohammed 2015).

Hasil tangkapan lobster jika dilihat berdasar ukurannya, ketiga HR memiliki ukuran yang sudah layak tangkap. Faktor yang memungkinkan hasil tangkapan lobster memiliki ukuran layak tangkap adalah penggunaan jaring dengan mesh size 5 inch. Penggunaan jaring dengan mesh size besar dan HR kecil merupakan kombinasi untuk membuat bukaan mata jaring sempurna, sehingga memungkinkan lobster yang berukuran kecil dapat meloloskan diri.

Penggunaan HR 29\% membuat bukaan mata jaring semakin sempurna sehingga lobster yang tertangkap lebih mudah dilepaskan dari puntalan jaring dengan HR yang besar. Berdasarkan wawancara dengan nelayan selama penelitian berlangsung, penggunaan jaring dengan HR yang kecil, pelepasan lobster dari puntalan jaring menjadi lebih mudah. Menurut De Cross (2009), penangkapan dengan alat tangkap pasif jika dilakukan pengurangan HR membuat ikan yang tertangkap pada jaring lebih mudah dilepaskan.

Berdasarkan penjelasan penggunaan bahan jaring pada desain jaring insang dasar dapat dikatakan bahwa jumlah mata yang digunakan semakin sedikit saat HR semakin kecil. Desain HR 41\% dan 29\% membutuhkan bahan jaring yang lebih sedikit daripada HR $52 \%$ yang biasa dipakai nelayan. Hal ini berdampak pada penurunan biaya yang harus dikeluarkan nelayan untuk membuat jaring insang dasar.

HR $29 \%$ dalam satu pis jaring membutuhkan 639 mata antar pemberat, HR 41\% membutuhkan 852 mata antar pemberat dan HR 52\% membutuhkan 1065 mata antar pemberat. Jika menggunakan desain HR 29\% maka sudah melakukan efisiensi mata jaring sebanyak 426 untuk setiap pis. Nelayan dalam seka- 
li pengoperasian jaring insang biasanya menggunakan paling sedikit 17 pis. Maka nilai efisiensi yang dapat diberikan untuk setiap kali pengoperasian alat tangkap adalah sebanyak 7242 mata jaring. Menurut Wardono (2016), perubahan efisiensi pada kegiatan penangkapan ikan akan berpengaruh terhadap penggunaan alokasi sumberdaya yang digunakan.

Jika dihubungkan dengan modal yang harus dikeluarkan nelayan, jika modal (Rp 120.000,-/puk jaring) yang dikeluarkan untuk membeli jaring adalah sama, maka jaring dengan HR yang lebih kecil akan menghasilkan jaring yang lebih panjang. Hal ini dinilai akan menguntungkan nelayan yang menggunakannya, karena daya tangkap jaring lebih besar. Menurut Lucchetti et al. (2014), gillnet merupakan alat tangkap pasif dimana sebagai salah satu jenis alat tangkap pasif, panjang jaring sangat berpengaruh terhadap daya tangkap jaring.

Berdasarkan penjelasan sebelumnya bahwa perbedaan HR pada jaring insang dasar tidak berpengaruh terhadap karakteristik hasil tangkapan, yang meliputi: jumlah, proporsi layak tangkap, dan kelengkapan tubuhnya. Suatu percobaan alat tangkap yang telah diujikan memungkinkan hasil penelitian tidak memberikan perbedaan nyata atau tidak memberikan pengaruh. Hal tersebut dapat disebabkan oleh salah satu faktor yang tidak terduga dan tidak dapat dikendalikan manusia yaitu kondisi sumberdaya ikan itu sendiri (Sbrana et al. 2007; Zulkarnain 2012). Tidak adanya ikan yang tertangkap dalam ukuran terlalu besar atau terlalu kecil diduga dipengaruhi oleh pola migrasi ikan itu sendiri (faktor biologi) (De Cross 2009).

Berdasarkan komposisi hasil tangkapan pada setiap desain HR, penggunaan HR $29 \%$ memperoleh jumlah jenis hasil tangkapan sampingan yang paling sedikit yaitu 12 jenis daripada desain yang lain. Sehingga dapat dikatakan bahwa jaring insang dasar dengan HR 29\% lebih selektif terhadap jenis hasil tangkapan. Alat tangkap yang menangkap spesies ikan tertentu disebut sebagai alat tangkap yang selektif terhadap spesies (Martasuganda 2008). Jika suatu alat tangkap tidak memenuhi syarat selektifitas secara penuh, maka selektifitas alat tangkap dapat dilihat dari segi jenis ikan, ukuran ikan, atau yang lainnya (Ago et al. 2014).

Penentuan desain jaring insang terbaik berdasarkan scoring, desain jaring insang dengan HR 29\% memiliki nilai yang paling tinggi sehingga dapat dikatakan bahwa desain ini adalah desain terbaik untuk menangkap lobster. Seperti yang telah dijelaskan sebelum- nya bahwa desain jaring insang HR 29\% tidak memberikan beda nyata terhadap desain jaring lainnya (41\% dan $52 \%$ ) pada jumlah, proporsi ukuran layak tangkap, dan proporsi kelengkapan tubuh lobster. Namun desain ini memberikan perbedaan pada indikator kemudahan melepaskan lobster dari jaring, kebutuhkan bahan jaring dan komposisi jenis hasil tangkapan pada masing-masing desain jaring.

\section{KESIMPULAN}

Tidak ada perbedaan jumlah, ukuran dan kelayakan lobster yang tertangkap di antara 3 jaring insang dasar (HR 29\%, 41\%, dan 52\%). Namun, desain jaring dengan HR 29\% adalah yang terbaik karena mempermudah nelayan melepaskan lobster dari jaring, menangkap jumlah jenis hasil tangkapan paling sedikit dan desain memerlukan bahan jaring yang lebih sedikit.

\section{SARAN}

Saran yang dapat diberikan adalah sebaiknya nelayan menggunakan desain ja-ring insang dasar dengan HR 29\% sehingga efisiensi jaring dapat termanfaatkan. De-ngan modal yang biasa dikeluarkan nelayan maka akan menghasilkan jaring dengan ukuran lebih panjang.

\section{UCAPAN TERIMA KASIH}

Terima kasih penulis sampaikan kepada Lembaga Pengelola Dana Pendidikan (LPDP) Kementerian Keuangan RI yang telah memberikan bantuan dana penelitian sehingga penulis dapat menyelesaikan penelitian. Bantuan dana penelitian yang diberikan berdasarkan SK Direktur Utama Pendanaan Kegiatan Pendidikan Lembaga Pengelola Dana Pendidikan Nomor KEP-14/LPDP/2016 dan Surat Perjanjian Nomor: PRJ-4350 /LPDP.3/2016 tentang Beasiswa Tesis dan Disertasi Lembaga Pengelola Dana Pendidikan.

\section{DAFTAR PUSTAKA}

Acosta AR, Appeldoorn RS. 1995. Catching Efficiency and Selectivity of Gillnets and Trammel Nets in Coral Reefs from Southwestern Puerto Rico. Fisheries Research. 22: 175-196. 
Budiarti TW. 2012. Perubahan Gillnetter Menjadi Troll Liner di PPN Palabuhanratu. Marine Fisheries. 3(1): 83-89.

De Cross MDST. 2009. Gillnet Selectivity of Three Flying Fish, Cheilopogon nigricans (Bennett, 1846), Cypselurus poecilopterus (Valenciennes, 1846) and Cheilopogon suttoni (Whitle and Colefax, 1938) off The Northwestern Coast of Sri Lanka. Journal of Aquatic Sciences. 14(-): 15-28.

Ditjen P2HP KKP. 2015. Larangan Tangkap Lobster: Ekspor Lobster Bisa Meningkat Signifikan [Internet]. [diunduh Rabu 09 Maret 2016 pukul 10.25 WIB]. Tersedia pada: http://m.bisnis.com/industri/read/ 20150129/99/396347/larangan-tangkaplobster-ekspor-lobster-bisa-meningkatsignifikan.

Emmanuel BE, Chukwu LO, Azeez LO. 2008. Gillnet Selectivity and Catch Rates of Pelagic Fish in Tropical Coastal Lagoonal Ecosystem. African Journal of Biotechnology. 7(21): 3962-3971.

Fonseca P, Martins R, Campos A, Sobral P. 2005. Gill-net Selectivity off The Portuguese Western Coast. Fisheries Research. 73: 323-339.

Fridman AL. 1986. Perhitungan dalam Merancang Alat Penangkapan Ikan. Terjemahan Balai Pengembangan Penangkapan lkan Semarang. 304 hlm.

Haluan CCR, Purbayanto A, Sondita MFA. 2012. Studi Mengenai Proses Tertangkapnya dan Tingkah Laku Ikan terhadap Gillnet Millennium di Perairan Bondet, Cirebon. Marine Fisheries. 3(1): 7-13.

Hutubessy, Grace. 2011. Encircling Gillnet Selectivity for Oxeye Scad (Selar boops Cuvier, 1833) in the Coast of Waai, Ambon Island. Journal of Coastal Development. 14(2): 125-130.

Kembaren DD, Nurdin E. 2015. Distribusi Ukuran dan Parameter Populasi Lobster Pasir (Panulirus homarus) di Perairan Aceh Barat. BAWAL. 7(3): 121-128.

Lubis E, Sumiati. 2011. Pengembangan Industri Pengolahan Ikan Ditinjau dari Produksi Hasil Tangkapan di PPN Palabuhanratu. Marine Fisheries. 2(1): 39-49.

Lucchetti A, Buglioni G, Conides A, Klaoudatos D, Sartor P, Sbrana M, Spedicato MT, Stamatopoulos C. 2014. Technical Measures Without Enforcement Tools: Is
There Any Sense? A Methodological Approach for the Estimation of Passive Net Length in Small Scale Fisheries. Mediterranean Marine Science. 16(1): 82-89.

Martasuganda, Sulaeman. 2008. Jaring Insang (Gillnet). Departemen Pemanfaatan Sumberdaya Perikanan dan Pusat Kajian Sumberdaya Pesisir dan Lautan. Bogor (ID): Institut Pertanian Bogor.

Martasuganda S, Matsuoka T, Kawamura G. 2000. Effect of Hang-in Ratio on SizeSelectivity of Gillnet. Nihon Suisan Gakkaishi. 66(3): 439-445.

Martasuganda S, Ogura Y, Matsuoka T, Kawamura G. 1999. Point Against Tactile Stimulation and its Effect to Forward Motion of Fish Upon Contact with a Mesh. Nihon Suisan Gakkaishi. 65 (6): 991-997.

Mohammed, MO. 2015. Gillnets and Their Efficiency in Fishing Activity. International Journal af Forest, Soil and Erosion (IJFSE). 5(1): 1-7.

Nurani TW, Wisudo SH, Imron M. 2012. Implementasi Manajemen Mutu pada Industri Penangkapan Ikan. Marine Fisheries. 3(2): 103-113.

Orsay B, Murside D. 2011. Catch Efficiency of Monofilament Gill Nets Configured at Various Colors and Hanging Ratios. Journal of Animal and Veterinary Advances. 10(9): 1219-1226.

Parsa M, Paighambari SY, Ghorbani R, Shabani MJ. 2014. Effects of Hanging Ratio on the CPUE of Tuna Drifting Gillnets in Bushehr Coastal Waters, Persian Gulf (Iran). World Journal of Fish and Marine Sciences. 6(3): 214-218.

Peraturan Menteri Kelautan dan Perikanan Republik Indonesia Nomor 56/ PERMENKP/ 2016 tentang Larangan Penangkapan dan/atau Pengeluaran Lobster (Panulirus spp.), Kepiting (Scylla spp.), dan Rajungan (Portunus pelagicus spp.) dari Wilayah Negara Republik Indonesia.

Pet JS, Pet-Soede C, van Densen WLT. 1995. Comparison of Methods for the Estimation of Gillnet Selectivity to Tilapia, Cyprinids and Other Fish Species in a Sri Lankan Reservoir. Fisheries Research. 24: 141-164.

Samaranayaka A, Engas A, Jorgansen T. 1997. Effects of Hanging Ratio and Fishing Depth on the Catch Rates of Drifting 
Tuna Gillets in Sri Lankan Waters. Fisheries Research. 29(1997): 1-12.

Sbrana M, Belcari $P$, De Ranieri S, Sartor P, Viva C. 2007. Comparison of The Catches of European Lake (Merluccius merluccius, L. 1758) Taken with Experimental Gillnets of Different Mesh Sizes in the Northern Tyrrhenian Sea (Western Mediterranean). Scientia Marina. 71(1): 47-56.

Sobari MP, Diniah, Widiarso DI. 2008. Analisis "Maximum Sustainable Yield" dan "Maximum Economic Yield" menggunakan Bio-Ekonomik Model Statis Gordon-Schaefer dari Penangkapan Spiny Lobster di Wonogiri. Jurnal IImu-ilmu Perairan dan Perikanan Indonesia. 15(1): 35-40.

Syofyan I, Syaifuddin, Cendana F. 2010. Studi Komparatif Alat Tangkap Jaring Insang
Hanyut (Drift Gillnet) Bawal Tahun 1999 dengan Tahun 2007 di Desa Meskom Kecamatan Bengkalis Kabupaten Bengkalis Propinsi Riau. Jurnal Perikanan dan Kelautan. 15(1): 62-70.

Walpole. 1995. Pengantar statistika. Diterjemahkan oleh Bambang Sumantri. Cetakan ke enam. Jakarta: PT Gramedia.

Wardono B. 2016. Efisiensi, Produktivitas dan Indeks Ketidakstabilan Perikanan Tuna Longline dan Pancing Tonda. Marine Fisheries. 7(1): 1-11

Zulkarnain. 2012. Rancang Bangun Bubu Lipat Modifikasi dan Penggunaan Cacing Tanah (Lumbricus rebellus) sebagai Umpan Alternatif untuk Penangkapan Spiny Lobster [Disertasi]. Bogor (ID): Institut Pertanian Bogor. 